\title{
Effects of stimulating the cGMP pathway on spontaneous activity in pacemaker cells isolated from the rabbit urethra Gerard Sergeant ${ }^{1}$, Lovise Johnston ${ }^{2}$, Noel McHale ${ }^{1}$, Mark Hollywood ${ }^{1}$ and Keith Thornbury*1
}

\author{
Address: ${ }^{1}$ Dundalk Institute of Technology, Dundalk, Ireland and ${ }^{2}$ Queen's University, Belfast, UK \\ Email: Keith Thornbury* - keith.thornbury@dkit.ie \\ * Corresponding author
}

from 2nd International Conference of cGMP Generators, Effectors and Therapeutic Implications

Potsdam, Germany, 10-12 June, 2005

Published: 16 June 2005

BMC Pharmacology 2005, 5(SuppI I):S34 doi:I0.I I86/I47I-22I0-5-SI-S34

Nitric oxide (NO) is the main inhibitory transmitter in the urethra [1] but little is known about how it mediates relaxation in this tissue. One possibility is that NO inhibits the $\mathrm{Ca}^{2+}$ oscillations underlying spontaneous electrical activity in the urethra and consequently reduces tone. We have recently demonstrated the presence of specialized, spontaneously active cells in the rabbit urethra that resemble interstitial cells of Cajal (ICC) in the gut. We hypothesized that urethral interstitial cells (IC) serve to drive the surrounding bulk smooth muscle and thus may contribute significantly to the generation of urethral tone and its modulation by neurotransmitters [2-4]. The purpose of the present study was to examine if spontaneous $\mathrm{Ca}^{2+}$ oscillations in isolated urethral IC were altered by NO donors and other activators of the CGMP pathway. Rabbits were humanely killed with pentobarbitone (I.V.) and their urethras removed. Cells were isolated as previously described [2] and incubated for 15 minutes at room temperature with the fluorescent $\mathrm{Ca}^{2+}$-sensitive indicator Fluo-4AM $(2 \mu \mathrm{M})$. Cells were then plated onto glass-bottomed petri dishes for 30 minutes before being perfused with Hanks solution. Single cell imaging was performed at 5-15 frames $\sec ^{-1}$ using a Nipkow spinning disk laser confocal microscope. When cells were maintained at $37^{\circ} \mathrm{C}$ calcium waves usually initiated at one or more discrete sites and then propagated throughout the cell as recently reported [5]. Wave amplitudes were calculated as a ratio $\left(\Delta \mathrm{F} / \mathrm{F}_{0}\right)$ by dividing the mean intensity of the ROI during the peak of the wave by the mean intensity during quiescent periods. The waves occurred at a mean frequency of $5.5 \pm 0.4 \mathrm{~min}^{-1}$ and had peak amplitudes of $1.6 \pm 0.2(\Delta \mathrm{F} /$ $\left.\mathrm{F}_{0}, \mathrm{n}=42\right)$. These were abolished in the presence of ryanodine $(30 \mu \mathrm{M}, \mathrm{n}=12)$ or tetracaine $(100 \mu \mathrm{M} \mathrm{n}=12)$, sug- gesting that calcium waves were dependant on functional RyR. In contrast, application of the $\mathrm{IP}_{3} \mathrm{R}$ blocker $2 \mathrm{APB}$ $(100 \mu \mathrm{M})$ failed to reduce wave frequency $(4.8 \pm 0.5 \mathrm{com}$ pared to $4.1 \pm 0.4 \mathrm{~min}^{-1}$ ) but reduced the spatial spread of the $\mathrm{Ca}^{2+}$ wave suggesting that $\mathrm{IP}_{3} \mathrm{R}$ were necessary for propagation of the waves. Application of the NO donor DEA-NO $(30 \mu \mathrm{M})$, also failed to reduce the frequency of the $\mathrm{Ca}^{2+}$ waves but reduced their spatial spread from 83.25 \pm 2.5 to $34.9 \pm 5.6 \mu \mathrm{m}(\mathrm{n}=5, \mathrm{p}<0.05)$, as did $8 \mathrm{Br}$ cGMP $(1 \mathrm{mM}$; from $83.54 \pm 17.23$ to $28.26 \pm 9.1 \mu \mathrm{m}, \mathrm{n}=4, \mathrm{p}<$ $0.05)$. A reduction in spatial spread also occurred on application of the protein kinase GI activator SP-8BrcGMPs $(25 \mu \mathrm{M})$. In 4 cells, $\mathrm{Ca}^{2+}$ waves propagated 103 $\pm 19.25 \mu \mathrm{m}$ under control conditions compared to $39.2 \pm$ $9.2 \mu \mathrm{m}$ in the presence of SP-8-BrcGMPs $(\mathrm{n}=4, \mathrm{p}<0.05)$.

Given the similarity between the effects of the $\mathrm{IP}_{3} \mathrm{R}$ blocker 2-APB and the activators of cGMP/GK pathway, these data suggest that NO may mediate its effects by interfering with $\mathrm{IP}_{3} \mathrm{R}$ and thus prevent propagation of the $\mathrm{Ca}^{2+}$ signal in rabbit IC.

\section{Acknowledgements}

This work was supported by the Wellcome Trust (grant no 064212) and a Department of Education and Learning (N.I.) studentship to Louise Johnston

\section{References}

I. Andersson KE: Neurotransmission and drug effects in urethral smooth muscle. Scand J Urol Nephrol Suppl 200I, 207:26-34.

2. Sergeant GP, Hollywood MA, McCloskey KD, Thornbury KD McHale NG: Specialised pacemaking cells in the rabbit urethra. J Physiol 2000, 526:359-66.

3. Sergeant GP, Hollywood MA, McCloskey KD, McHale NG, Thornbury KD: Role of IP(3) in modulation of spontaneous activity 
in pacemaker cells of rabbit urethra. Am J Physiol Cell Physiol 200I, 280:CI349-56.

4. Sergeant GP, Thornbury KD, McHale NG, Hollywood MA: Characterization of norepinephrine-evoked inward currents in interstitial cells isolated from the rabbit urethra. Am J Physiol Cell Physiol 2002, 283:C885-94.

5. Johnston L, Sergeant GP, Hollywood MA, Thornbury KD, McHale NG: Calcium oscillations in interstitial cells of the rabbit urethra. J Physiol 2005.

Publish with Bio Med Central and every scientist can read your work free of charge

"BioMed Central will be the most significant development for disseminating the results of biomedical research in our lifetime. " Sir Paul Nurse, Cancer Research UK

Your research papers will be:

- available free of charge to the entire biomedical community

- peer reviewed and published immediately upon acceptance

- cited in PubMed and archived on PubMed Central

- yours - you keep the copyright

Submit your manuscript here:

http://www.biomedcentral.com/info/publishing_adv.asp 